\title{
Regulatory and Permitting Issues
}

\author{
Topical Report \\ West Coast Regional Carbon Sequestration Partnership \\ (WESTCARB)
}

Contract Period: October 1, 2003-September 30, 2005

Terralog Technologies USA, Inc.

September 30, 2005

DOE Contract No.: DE-FC26-03NT41984

Submitted by:

Larry Myer

PIER Program

California Energy Commission

1516 Ninth Street, MS-43

Sacramento, California 95814

Prepared by:

Terralog Technologies USA, Inc.

332 E. Foothill Boulevard

Arcadia, California 91006 


\section{United States Government Disclaimer}

This report was prepared as an account of work sponsored by an agency of the United States Government. Neither the United States Government nor any agency thereof, nor any of their employees, makes any warranty, express or implied, or assumes any legal liability or responsibility for the accuracy, completeness, or usefulness of any information, apparatus, product, or process disclosed, or represents that its use would not infringe privately owned rights. Reference herein to any specific commercial product, process, or service by trade name, trademark, manufacturer, or otherwise does not necessarily constitute or imply its endorsement, recommendation, or favoring by the United States Government or any agency thereof. The views and opinions of authors expressed herein do not necessarily state or reflect those of the United States Government or any agency thereof.

\section{California Energy Commission Disclaimer}

This report was prepared as a result of work sponsored by the California Energy Commission (Energy Commission). It does not necessarily present the views of the Energy Commission, its employees, or the State of California. The Energy Commission, the State of California, its employees, contractors, and subcontractors make no warranty, express or implied, and assume no legal liability for the information in this report; nor does any party represent that the use of this information will not infringe upon privately owned rights. This report has not been approved or disapproved by the Energy Commission, nor has the Energy Commission passed upon the accuracy or adequacy of this information in this report.

\section{Terralog Disclaimer}

This report was prepared as an account of work sponsored by the Department of Energy. Neither Terralog Technologies nor anyone acting on behalf of Terralog Technologies:

1. Makes any warranty or representation, express or implied, with respect to the accuracy, completeness, or usefulness of the information contained in this report, or that the use of any apparatus, method, or process disclosed in this report may not infringe privately owned rights; or,

2. Assumes any liability with respect to the use of, or for damages resulting from the use of, any information, apparatus, method, or process disclosed in this report. 


\begin{abstract}
As part of the West Coast Regional Carbon Sequestration Partnership (WESTCARB), Terralog Technologies USA, Inc., reviewed current state and federal regulations related to carbon dioxide capture and storage within geologic formations and enhanced carbon uptake in terrestrial ecosystems. We have evaluated and summarized the current and possible future permitting requirements for the six states that comprise the West Coast Regional Partnership. Four options exist for $\mathrm{CO}_{2}$ injection into appropriate geologic formations, including storage in: (1) oil and gas reservoirs, (2) saline formations, (3) unmineable coal beds, and (4) salt caverns. Terrestrial $\mathrm{CO}_{2}$ sequestration involves improved carbon conservation management (e.g. reduction of deforestation), carbon substitution (e.g., substitution for fossil fuel-based products, energy conservation through urban forestry, biomass for energy generation), and improved carbon storage management (e.g., expanding the storage of carbon in forest ecosystems). The primary terrestrial options for the West Coast Region include: (1) reforestation of under-producing lands (including streamside forest restoration), (2) improved forest management, (3) forest protection and conservation, and (4) fuel treatments for the reduction of risk of uncharacteristically severe fires (potentially with associated biomass energy generation). The permits and/or contracts required for any land-use changes/disturbances and biomass energy generation that may occur as part of WESTCARB's activities have been summarized for each state.
\end{abstract}




\section{Table of Contents}

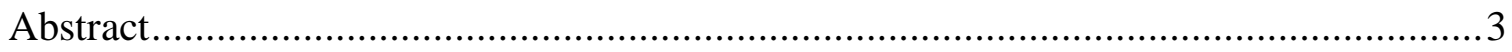

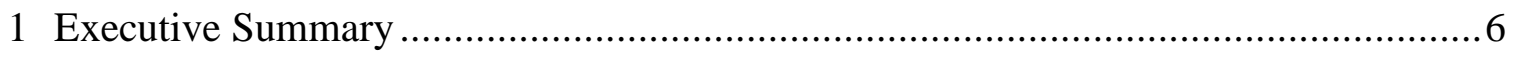

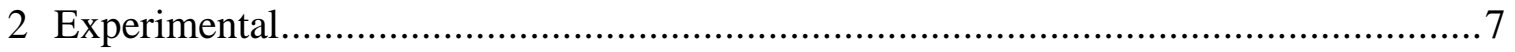

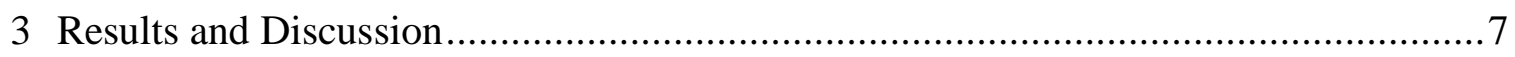

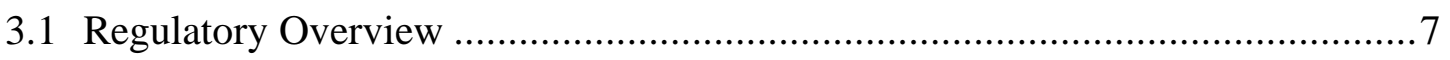

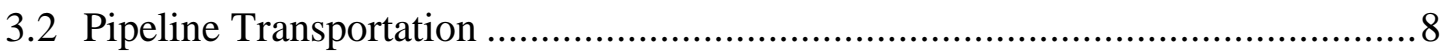

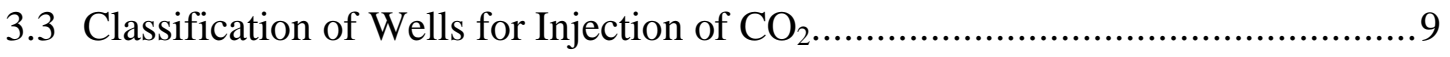

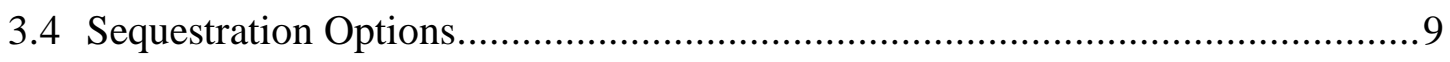

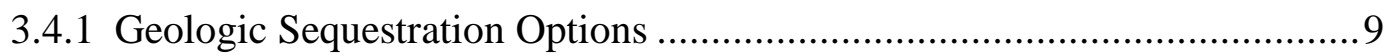

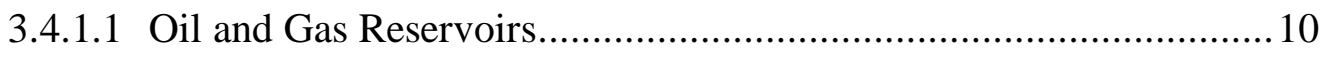

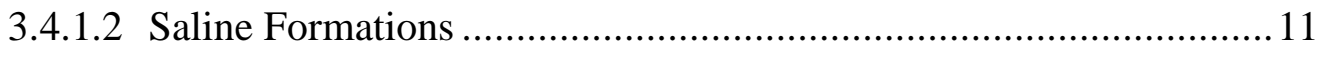

3.4.1.3 Methane-Bearing Coal Beds...................................................... 13

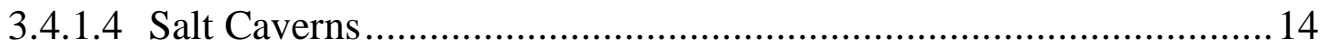

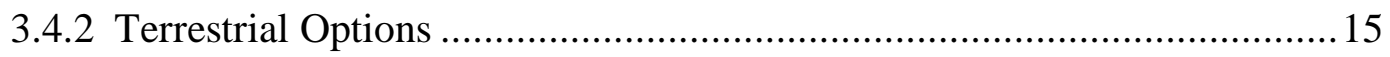

3.4.2.1 Land-Use Changes or Disturbances ............................................... 16

3.4.2.2 Biomass Energy Generation ........................................................ 20

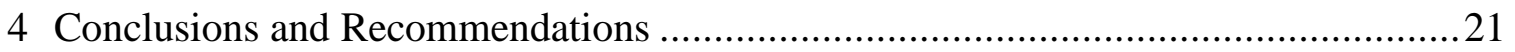

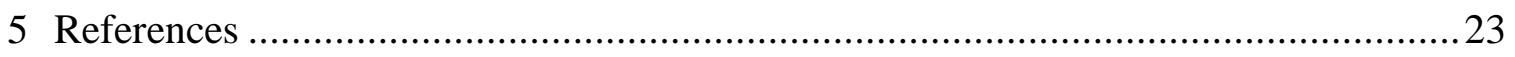

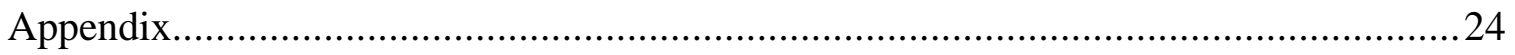

\section{List of Figures}

Figure 1. North America coal bed methane resource map ......................................... 14

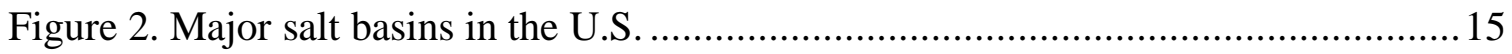

\section{List of Tables}

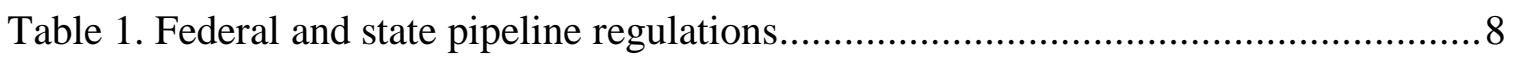

Table 2. Federal and state EOR permit requirements ..............................................11

Table 3. Federal and state potential permit requirements for $\mathrm{CO}_{2}$ injection NOT related to

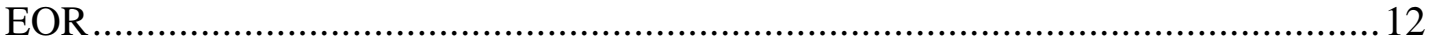

Table 4. Federal and state potential coal-bed methane permit requirements .................. 13

Table 5. Potential salt cavern permit requirements ..................................................... 15

Table 6. Potential Arizona permits/contracts for land-use changes or disturbances......... 17

Table 7. Potential California permits/contracts for land-use changes or disturbances .....18

Table 8. Potential Oregon permits/contracts for land-use changes or disturbances .........19

Table 9. Potential Washington permits/contracts for land-use changes or disturbances ..20 
Table 10. Biomass permit/contract requirements

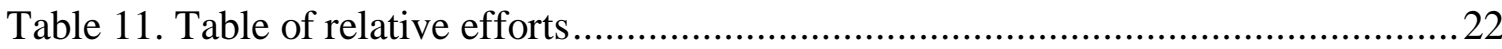




\section{Executive Summary}

In 1997, the U.S. Department of Energy (DOE) started the Carbon Sequestration Program. Carbon dioxide $\left(\mathrm{CO}_{2}\right)$ is a potent greenhouse gas. Carbon dioxide capture and storage within geologic formations and enhanced carbon uptake in terrestrial ecosystems are the two main sequestration options. Seven Regional Carbon Sequestration Partnerships were formed; Terralog Technologies belongs to the West Coast Regional Carbon Sequestration Partnership (WESTCARB) and is responsible for reporting on the regulatory and permitting issues for $\mathrm{CO}_{2}$ sequestration.

Carbon dioxide generated from industrial activities can be sequestered through capturing, transporting, and injecting it into appropriate geologic formations, or through uptake by terrestrial ecosystems. For injection into appropriate geologic formations, options include storage in:

- Oil and gas reservoirs,

- Saline formations,

- Unmineable coal beds, and

- Salt caverns.

Injection of $\mathrm{CO}_{2}$ into geologic formations requires an Underground Injection Control (UIC) permit from the U.S. Environmental Protection Agency (EPA). EPA has delegated primary regulatory authority to state agencies that have demonstrated an ability to implement UIC programs that meet EPA requirements. These states are referred to as "primacy states". In states that have not received primacy status, the responsible permitting agency is EPA. Currently, EPA does not differentiate between $\mathrm{CO}_{2}$ storage and $\mathrm{CO}_{2}$ disposal in any geologic formation, but is endeavoring to ensure a universal standard and perhaps classification to which all agencies will adhere. The permit requirements for each of the above options have been documented and their respective regulations cited. We suggest that EPA should promulgate the ruling with input from the states and standardize the different regulations that exist for different states.

Terrestrial $\mathrm{CO}_{2}$ sequestration involves improved carbon conservation management (e.g. reduction of deforestation), carbon substitution (e.g., substitution for fossil fuel-based products, energy conservation through urban forestry, biomass for energy generation), and improved carbon storage management (e.g., expanding the storage of carbon in forest ecosystems). Terrestrial options available to the WESTCARB partnership are:

- Reforestation of under-producing lands (including streamside forest restoration),

- Improved forest management,

- Forest protection and conservation, and

- Fuel treatments for the reduction of risk of uncharacteristically severe fires (potentially with associated biomass energy generation). 
The required permit/contract for any land use changes/disturbances and biomass energy generation have been summarized for each state. To date, biomass energy generation is not economically feasible without some form of government subsidy or tax credit.

\section{Experimental}

No experiment was performed for this report. All regulatory reviews and $\mathrm{CO}_{2}$ sequestration options are described in detail under their respective headings (see Table of Contents).

\section{Results and Discussion}

\subsection{Regulatory Overview}

Carbon dioxide $\left(\mathrm{CO}_{2}\right)$ generated from industrial activities can be sequestered by capturing, transporting, and injecting it into appropriate geologic formations, or through uptake by terrestrial ecosystems. It is generated by power plants, natural gas operations, refineries, iron and steel industry, petrochemical industries, and hydrogen or methanol production (Herzog et al., 1997). $\mathrm{CO}_{2}$ is not currently listed as hazardous waste, and it is not regulated under the Clean Water Act (68FR52922-52933).

Injection of $\mathrm{CO}_{2}$ into appropriate geologic formations requires an Underground Injection Control (UIC) permit from the U.S. Environmental Protection Agency (EPA). The UIC Program was established under the provisions of the Safe Drinking Water Act of 1974 to protect underground sources of useable water. Under this program, five classifications of wells were established:

- Class I - wells used to inject liquid hazardous wastes, industrial nonhazardous liquid, and municipal wastewater beneath the lowermost drinkingwater reservoir;

- Class II - wells used to dispose of fluids associated with the production of oil and natural gas, enhanced oil recovery, and storage of liquid hydrocarbon;

- Class III - wells used to inject fluids for the extraction of minerals;

- Class IV - wells used to dispose of hazardous or radioactive wastes into or above drinking water. EPA has banned the use of these Class IV wells; and

- Class V - wells not included in the other classes used to generally inject nonhazardous fluid into or above drinking water.

See "Classification of Wells for Injection of $\mathrm{CO}_{2}$ " (below) for a discussion of permitting of underground $\mathrm{CO}_{2}$ injection under existing UIC regulations. 
EPA has delegated primary regulatory authority to state agencies that have demonstrated an ability to implement UIC programs that meet EPA requirements. These states are referred to as "primacy states". In many of these states, more than one state agency has primary regulatory authority for one or more classes of injection wells. In states that have not received primacy, the responsible agency is EPA.

\subsection{Pipeline Transportation}

The most economical means of transporting captured $\mathrm{CO}_{2}$ is by pipelines. Depending on supply and demand, the transportation of $\mathrm{CO}_{2}$ may involve temporary storage in either some storage tanks or geological reservoirs before the $\mathrm{CO}_{2}$ is permanently disposed of within geologic formations.

Pipelines are regulated by U.S. Department of Transportation (DOT), Occupational Safety and Health Administration's (OSHA's) confined space regulation, and each State's Fire Marshall or Public Utility Commission (PUC). In addition, pipelines from wellhead to lease property may be regulated by each State's equivalent of a Division of Oil and Gas. Table 1 (below) shows the regulations cited by Federal authorities and the responsible state agencies.

Table 1. Federal and state pipeline regulations. (See Appendix I for an explanation of acronyms.)

\begin{tabular}{|l|l|l|}
\hline $\begin{array}{l}\text { STATE/ } \\
\text { FEDERAL }\end{array}$ & $\begin{array}{l}\text { REGULATING } \\
\text { AGENCY }\end{array}$ & REGULATIONS CITED \\
\hline Federal & $\begin{array}{l}\text { DOT } \\
\text { OSHA (confined } \\
\text { space) } \\
\text { FERC } \\
\text { (construction) }\end{array}$ & $\begin{array}{l}\text { 49CFR190-199 } \\
\text { 29CFR1910.146 }\end{array}$ \\
\hline Alaska & Defer to DOT & 49CFR195 \\
\hline Arizona & $\begin{array}{l}\text { Arizona Corporate } \\
\text { Commission }\end{array}$ & ACC R14-5-201 to R14-5-205 \\
\hline California & $\begin{array}{l}\text { Fire Marshall } \\
\text { DOGGR }\end{array}$ & $\begin{array}{l}\text { Gov. Code Sec 51010 to 51019.1, AB592 } \\
\text { DOGGR Pipeline regulations }\end{array}$ \\
\hline Nevada & $\begin{array}{l}\text { Public Service } \\
\text { Commission }\end{array}$ & NAC 704.455 to 704.465 \\
\hline Oregon & PUC & PUC Div.31, 860-031-0001 to 860-031-0041 \\
\hline Washington & UTC & $\begin{array}{l}\text { House Bill 2420, Ch191, Laws of 2000, } \\
\text { RCW Ch81.11 }\end{array}$ \\
\hline
\end{tabular}

$\mathrm{CO}_{2}$ may also be temporary stored in Aboveground Storage Tanks (AST) and transported via pipeline to its final sequestered location at some later time. There is no regulation for $\mathrm{CO}_{2}$ in aboveground tanks; however, AST is subjected to American Petroleum Institute 
standards, Underwriters Laboratories Inc. requirements, and American Water Works Association guidelines.

\subsection{Classification of Wells for Injection of $\mathrm{CO}_{2}$}

All six western States belonging to WESTCARB (i.e., Alaska, Arizona, California, Nevada, Oregon, and Washington) define $\mathrm{CO}_{2}$ as a product when used with enhanced oil recovery (EOR) projects; hence, $\mathrm{CO}_{2}$ can be injected into a well classified as Class II. For $\mathrm{CO}_{2}$ injection not related to EOR, the classification of $\mathrm{CO}_{2}$ as a product or a waste will influence the type of injection well as well as the regulating agency.

The regulations on $\mathrm{CO}_{2}$ injection wells are currently in flux. It has been suggested by some that $\mathrm{CO}_{2}$ injection wells should be classified in EPA UIC Class II category (IOGCC, 2005). As of the writing of this report, the authors understand that EPA will probably make no distinction between storage and disposal into any medium such as oil and gas reservoirs, saline formations, coal beds, or salt, nor will EPA distinguish whether the $\mathrm{CO}_{2}$ is in gaseous or liquid phase. EPA Region $\mathrm{X}$, which includes Alaska, Oregon, and Washington, will probably permit $\mathrm{CO}_{2}$ injection wells as Class $\mathrm{V}$ regardless of whether they are for storage or disposal with permit conditions similar to Class I. However, EPA Region IX will probably permit these well as Class I. EPA needs to ensure that injection wells will have the same standard, regardless of the well classification, and should ensure a universal standard to which all primacy-state agencies will adhere. Ultimately EPA, with input from the States, will have to decide on the proper classification of $\mathrm{CO}_{2}$.

\subsection{Sequestration Options}

$\mathrm{CO}_{2}$ can either be injected into suitable geologic formations or be captured through uptake by terrestrial ecosystems.

\subsubsection{Geologic Sequestration Options}

Currently, the only permits issued for $\mathrm{CO}_{2}$ injection within the six States belonging to WESTCARB are for EOR-related injection. The States and the Federal government make no clear distinction between $\mathrm{CO}_{2}$ storage and $\mathrm{CO}_{2}$ disposal and, at this time, it appears that EPA will probably treat the storage and disposal of $\mathrm{CO}_{2}$ by injection in the same category. The responsible agency involved with permitting depends on whether the injection is located on State, Federal or Indian lands and if the state has primacy status with EPA.

For injection on Indian lands, EPA will be the permitting agency. As of the writing of this report, no Indian Nation has primacy status; however, the Navajo Nation is close to obtaining primacy status. For injection on Federal lands, EPA will also be the regulatory agency, and will notify the corresponding state agency and the Bureau of Land Management of the injection. For injection on State lands, the responsible agency will depend on whether or not the state has primacy status with EPA. 
The options for geologic sequestration of $\mathrm{CO}_{2}$, including storage in:

- Oil and gas reservoirs,

- Saline formations,

- Unmineable coal beds, and

- Salt caverns.

Are outlined in the following sections.

\subsubsection{Oil and Gas Reservoirs}

$\mathrm{CO}_{2}$ injected into oil and gas reservoirs for enhanced oil recovery (EOR) is currently classified as Class II by all 6 western States. $\mathrm{CO}_{2}$ is classified as a product to enhance the recovery of hydrocarbons in depleted fields. In places where states have primacy, the agencies involved (see Table 2) have control over the Class II well. In states where EPA shares primacy, e.g. Alaska and California; EPA and the state will jointly administer the Class II program. In California, the Division of Oil, Gas, and Geothermal Resources (DOGGR) will issue a Class II well permit. In Alaska, the Oil and Gas Conservation Commission (OGCC) will issue a Class IIR (Enhanced Recovery) well permit for the EOR well. Arizona has no primacy status, so EPA will issue a Class II well permit. However, Arizona OGCC has secondary jurisdiction and an Aquifer Protection Permit is also required from the Department of Environmental Quality (DEQ). A well permitted by EPA may start out as Class II when there is EOR activity, but when EOR activity stops,

the well will be reclassified as either Class I or V depending on which EPA jurisdiction it falls within. 
Table 2. Federal and state EOR permit requirements. (See Appendix I for an explanation of acronyms.)

\begin{tabular}{|c|c|c|c|}
\hline STATE & $\begin{array}{l}\text { REGULATING } \\
\text { AGENCY }\end{array}$ & $\begin{array}{l}\text { WELL/PERMIT } \\
\text { TYPE }\end{array}$ & REGULATIONS CITED \\
\hline Alaska & $\begin{array}{l}\text { EPA } \\
\text { OGCC share } \\
\text { primacy w/EPA }\end{array}$ & Class IIR & $\begin{array}{l}\text { 40CFR144-148 } \\
\text { 20AAC25; 31 AK O\&G } \\
\text { Consvr. Act Ch31.05 }\end{array}$ \\
\hline Arizona & $\begin{array}{l}\text { EPA no primacy } \\
\text { w/state } \\
\text { OGCC } \\
\text { DEQ }\end{array}$ & $\begin{array}{l}\text { Class II } \\
2^{\text {nd }} \text { jurisdiction } \\
\text { Aquifer Protection } \\
\text { Permit } \\
\end{array}$ & $\begin{array}{l}\text { 40CFR144-148 } \\
\text { 12AAC7; ARS 27-516 } \\
\text { ARS 49-241; 18AAC,Ch9 }\end{array}$ \\
\hline California & $\begin{array}{l}\text { EPA } \\
\text { DOGGR share } \\
\text { primacy w/EPA }\end{array}$ & Class II & $\begin{array}{l}\text { 40CFR144-148 } \\
\text { 14CCR Div2, Ch2, 4; } \\
\text { Public Resources Code } \\
30262\end{array}$ \\
\hline Nevada & $\begin{array}{l}\text { DEP } \\
\text { DOM } \\
\text { BLM }\end{array}$ & $\begin{array}{l}\text { Class II (Interagency } \\
\text { Cooperation between } 3 \\
\text { agencies) }\end{array}$ & $\begin{array}{l}\text { NAC445A.810 to } \\
\text { 445A.925 } \\
\text { NAC Ch522; NRS } \\
\text { 445A.470 } \\
\text { 43CFR Ch2 Part3160 }\end{array}$ \\
\hline Oregon & $\begin{array}{l}\text { DEQ } \\
\text { DOGAMI }\end{array}$ & $\begin{array}{l}\text { Class II } \\
\text { Interagency cooperation }\end{array}$ & $\begin{array}{l}\text { 40CFR144-148; } \\
\text { 44OAR340-044-0005 and } \\
\text { Appendix A } \\
\text { OAR Ch.632 Div. 10; ORS } \\
\text { 520 }\end{array}$ \\
\hline Washington & $\begin{array}{l}\text { Dept. of } \\
\text { Ecology } \\
\text { DNR }\end{array}$ & Class II (joint control) & $\begin{array}{l}\text { 40CFR144-148; WAC173- } \\
218 \\
78.52 \mathrm{RCW}\end{array}$ \\
\hline
\end{tabular}

Currently, all $\mathrm{CO}_{2}$ injection into oil and gas reservoirs is associated with EOR. The permitting situation for injection into depleted oil and gas reservoirs that will not be related to EOR or enhanced gas recovery (EGR) will likely be similar to that for saline formation. See the section on Saline Formations (below) for a discussion of how agencies might permit this type of injection.

\subsubsection{Saline Formations}

Regulations of $\mathrm{CO}_{2}$ injection in saline formations are not yet well defined and are not consistent between states. For example, Nevada, Oregon, and Washington prohibit Class I wells. In Oregon and Washington, EPA Region X will probably classify $\mathrm{CO}_{2}$ injection wells as Class V; however, Oregon only allows shallow Class V wells-less than $30 \mathrm{~m}$ (100 ft.) deep-because of subsurface conditions. In EPA Region IX, which includes 
Arizona, California, and Nevada, $\mathrm{CO}_{2}$ injection wells will most probably be classified as Class I; however, similar to Oregon, Nevada prohibits Class I wells because of subsurface conditions. It should be noted that the different classifications of $\mathrm{CO}_{2}$ wells is of lesser importance when compared to operational requirements (based on criteria, standards, geology, for example) for each $\mathrm{CO}_{2}$ injection application.

In Alaska, the OGCC permits disposal (including $\mathrm{CO}_{2}$ ) as Class IID wells. This classification depends on the fluid stream and a compatibility demonstration; for example, kitchen and compound wastes can be disposed of using Class IID well if the disposal is used for flooding purposes. Table 3 (below) summarizes permit conditions and regulations for $\mathrm{CO}_{2}$ injection not related to EOR.

Table 3. Federal and state potential permit requirements for $\mathrm{CO}_{2}$ injection NOT related to EOR. (See Appendix I for an explanation of acronyms.)

\begin{tabular}{|c|c|c|c|}
\hline STATE & $\begin{array}{l}\text { REGULATING } \\
\text { AGENCY }\end{array}$ & $\begin{array}{l}\text { WELL/PERMIT TYPE } \\
\text { (If not EOR related) }\end{array}$ & $\begin{array}{l}\text { REGULATIONS } \\
\text { CITED }\end{array}$ \\
\hline Alaska & $\begin{array}{l}\text { EPA } \\
\text { OGCC share Class } \\
\text { II primacy w/EPA }\end{array}$ & Class V & $\begin{array}{l}\text { 40CFR144-148 } \\
\text { 20AAC25; } 31 \text { AK } \\
\text { O\&G Consvr. Act } \\
\text { Ch31.05 }\end{array}$ \\
\hline Arizona & $\begin{array}{l}\text { EPA no primacy } \\
\text { w/state } \\
\text { OGCC }\end{array}$ & Class I & $\begin{array}{l}\text { 40CFR144-148 } \\
\text { 12AAC7; ARS 27- } \\
516\end{array}$ \\
\hline California & $\begin{array}{l}\text { EPA } \\
\text { DOGGR share } \\
\text { Class II primacy } \\
\text { w/EPA }\end{array}$ & Class I & $\begin{array}{l}\text { 40CFR144-148 } \\
\text { 14CCR Div2, Ch2, 4; } \\
\text { Public Resources } \\
\text { Code } 30262\end{array}$ \\
\hline Nevada & $\begin{array}{l}\text { DEP } \\
\text { DOM } \\
\text { BLM } \\
\text { joint interagency } \\
\text { cooperation } \\
\end{array}$ & $\begin{array}{l}\text { Unknown, Class I } \\
\text { prohibited }\end{array}$ & $\begin{array}{l}\text { NAC445A.810 to } \\
\text { 445A.925 } \\
\text { NAC Ch522; NRS } \\
\text { 445A.470 } \\
\text { 43CFR Ch2 Part3160 }\end{array}$ \\
\hline Oregon & $\begin{array}{l}\text { DEQ } \\
\text { DOGAMI }\end{array}$ & $\begin{array}{l}\text { Class V, <30 m (100 ft.) } \\
\text { well only } \\
\text { Interagency cooperation }\end{array}$ & $\begin{array}{l}44 \text { OAR 340-044- } \\
0005 \text { and Appendix A } \\
\text { OAR Ch.632 Div. 10; } \\
\text { ORS 520 }\end{array}$ \\
\hline Washington & Dept. of Ecology & Class V & $\begin{array}{l}\text { 40CFR144-148; } \\
\text { WAC173-218 }\end{array}$ \\
\hline
\end{tabular}




\subsubsection{Methane-Bearing Coal Beds}

Regulations for $\mathrm{CO}_{2}$ injection into coal beds for enhanced coal-bed methane (ECBM) recovery vary among the three WESTCARB states (Alaska, Arizona, and Washington) that have sizable deposits (Hart's E\&Pnet, see Figure 1). Washington (primacy status) has permitted one Class II injection well for ECBM. Since ECBM deals with hydrocarbon recovery, it appears that $\mathrm{CO}_{2}$ injection for ECBM would lead to a Class II classification. $\mathrm{CO}_{2}$ injection for ECBM can be thought of as a form of EGR. Alaska OGCC will jointly administer Class II well with EPA (share primacy) for EGR injection. Because Arizona has no primacy status, EPA will administer the Class II well program for EGR in this state. For non-EGR-related injection in states without primacy, EPA Region $\mathrm{X}$ most probably will permit the $\mathrm{CO}_{2}$ injection regardless if it is for storage or disposal as Class V well with permit conditions similar to Class I. EPA Region IX will most probably permit ECBM-related wells as Class I.

Storage of $\mathrm{CO}_{2}$ in ECBM produces a significant amount of water during the initial injection phase, and the disposal of the water produced may require a National Pollutant Discharge and Elimination System (NPDES) permit (Veil, 2002).

Table 4. Federal and state potential coal-bed methane permit requirements. (See Appendix I for an explanation of acronyms.)

\begin{tabular}{|c|c|c|c|}
\hline STATE & $\begin{array}{l}\text { REGULATING } \\
\text { AGENCY }\end{array}$ & $\begin{array}{l}\text { WELL/PERMIT } \\
\text { TYPE }\end{array}$ & REGULATIONS CITED \\
\hline Alaska & $\begin{array}{l}\text { EPA } \\
\text { OGCC share } \\
\text { primacy w/EPA }\end{array}$ & $\begin{array}{l}\text { Class V non EGR } \\
\text { related } \\
\text { Class II for EGR }\end{array}$ & $\begin{array}{l}\text { 40CFR144-148; CWA } \\
\text { 40CFR 122, 40CFR147.52 } \\
\text { 20AAC25; } 31 \text { AK O\&G } \\
\text { Consvr. Act Ch31.05 }\end{array}$ \\
\hline Arizona & $\begin{array}{l}\text { EPA no primacy } \\
\text { w/state } \\
\text { DEQ }\end{array}$ & $\begin{array}{l}\text { Class II for EGR } \\
\text { Class I non EGR } \\
\text { related } \\
\text { Aquifer Protection } \\
\text { Permit }\end{array}$ & $\begin{array}{l}\text { 40CFR144-148; CWA } \\
\text { 40CFR 122; 40CFR147.52 } \\
\text { ARS 49-241; 18AAC Ch9 }\end{array}$ \\
\hline Washington & $\begin{array}{l}\text { Dept. of } \\
\text { Ecology } \\
\text { DNR }\end{array}$ & $\begin{array}{l}\text { Class II } \\
\text { Waste Water Permit } \\
\text { Class II (joint control } \\
\text { with Dept. of Ecology }\end{array}$ & $\begin{array}{l}\text { 40CFR144-148; CWA } \\
\text { 40CFR 122, 40CFR147.52; } \\
\text { WAC173-218 } \\
\text { WAC173-226 } \\
78.52 \text { RCW }\end{array}$ \\
\hline
\end{tabular}




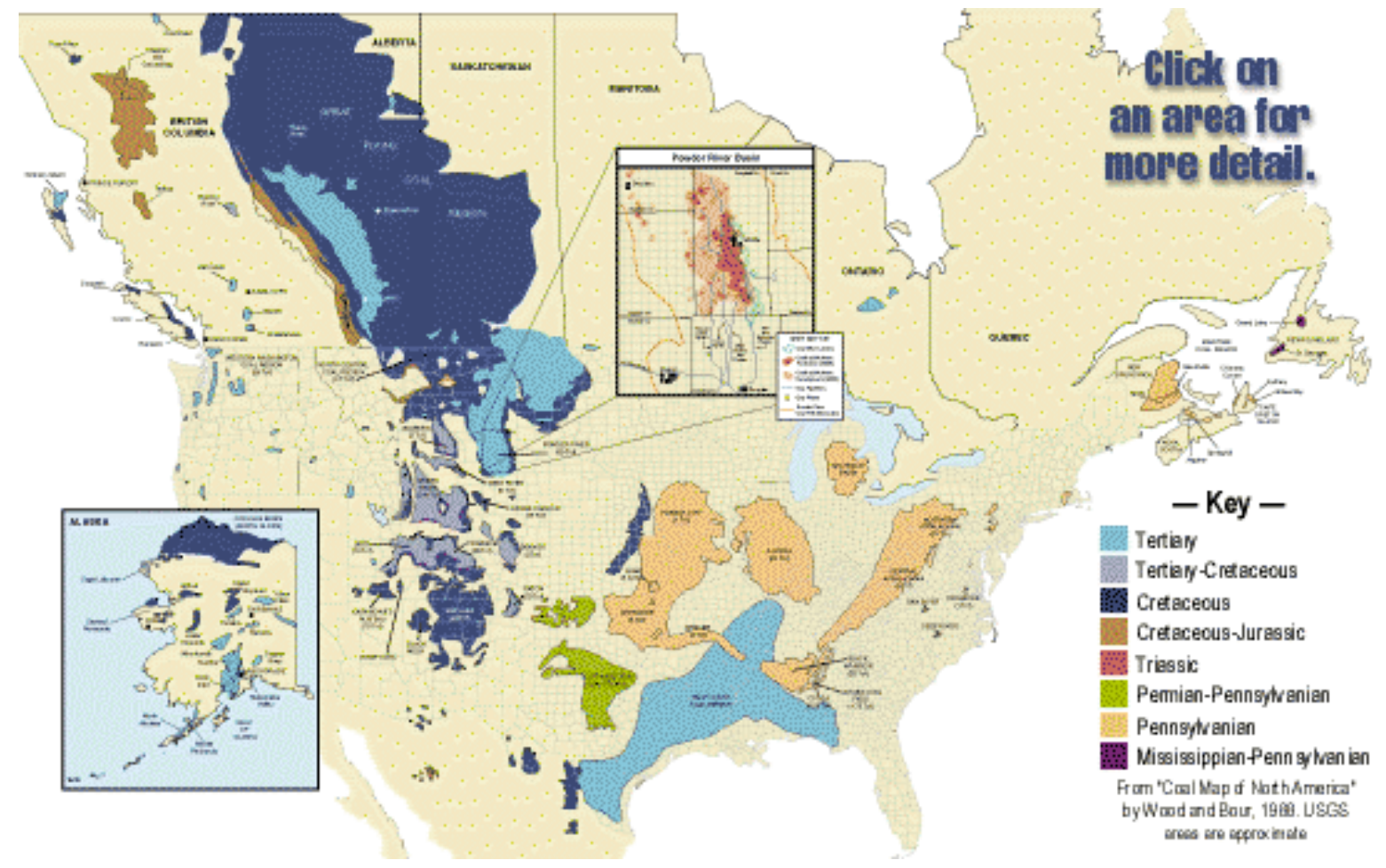

Figure 1. North America coal-bed methane resource map

Source: Hart's E\&P Magazine

\subsubsection{Salt Caverns}

Arizona is the only state within the West Coast Regional Carbon Sequestration Partnership that has sizable salt deposits (Figure 2). In Arizona, two classes of well are defined for this type of reservoir: (1) a Class I well permit is required to solution-mine salt deposits, and (2) a Class II well permit is required for the injection of $\mathrm{CO}_{2}$ into the caverns for EOR purposes. An Aquifer Protection Permit is also required. If $\mathrm{CO}_{2}$ injection is not related to EOR and is to be disposed or stored into salt cavern, a Class I permit will be maintained.

Table 5 shows the potential permit requirements for salt -cavern storage of $\mathrm{CO}_{2}$. 
Table 5. Potential salt cavern permit requirements. (See Appendix I for an explanation of acronyms.)

\begin{tabular}{|c|c|c|c|}
\hline STATE & $\begin{array}{l}\text { REGULATING } \\
\text { AGENCY }\end{array}$ & WELL/PERMIT TYPE & $\begin{array}{l}\text { REGULATIONS } \\
\text { CITED }\end{array}$ \\
\hline Arizona & $\begin{array}{l}\text { EPA } \\
\text { OGCC } \\
\text { DEQ }\end{array}$ & $\begin{array}{l}\text { Class I (solution mining } \\
\text { of salt and non EOR } \\
\text { related) } \\
\text { Class II (for EOR related } \\
2^{\text {nd }} \text { jurisdiction for Class } \\
\text { II } \\
\text { Aquifer Protection } \\
\text { Permit }\end{array}$ & $\begin{array}{l}\text { 40CFR144-148 } \\
\text { 12AAC Ch7 } \\
\text { ARS 49-241; } \\
\text { 18AAC,Ch9 }\end{array}$ \\
\hline
\end{tabular}

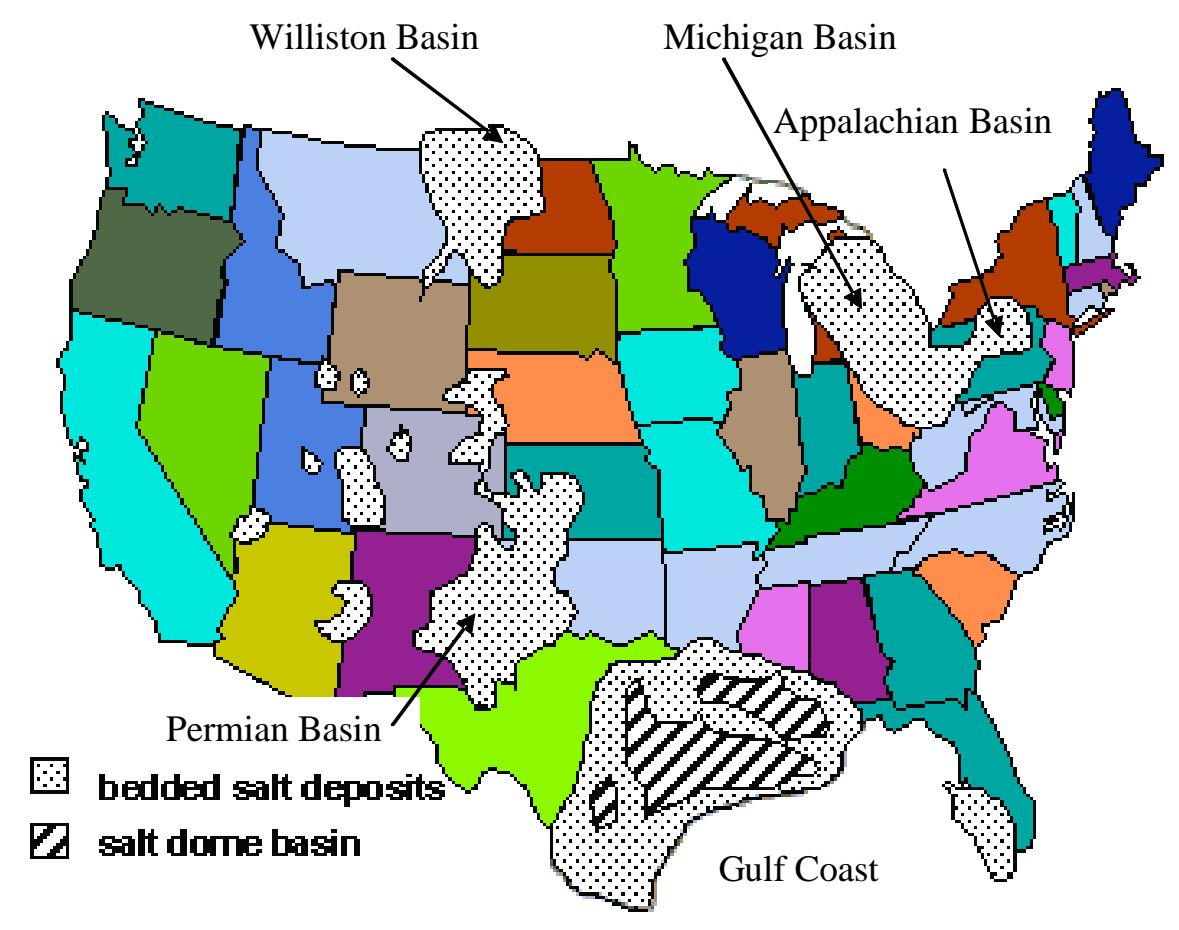

Source: National Petroleum Technology Office

Figure 2. Major salt basins in the U.S.

\subsubsection{Terrestrial Options}

Terrestrial $\mathrm{CO}_{2}$ sequestration options applicable to the WESTCARB region include carbon conservation, carbon substitution, and carbon storage. Carbon conservation deals with maintaining the forestland base, reducing deforestation, reducing forest degradation by protecting forests from fires and pests, and modifying forest management through 
extended rotation (as well as other techniques). Carbon substitution deals with substitution for fossil fuel-based products, energy conservation through urban forestry (e.g., reducing fossil fuel consumption by using shade trees to keep buildings cool), and biomass for energy generation. Carbon storage deals with afforestation (forestation of previously unforested land), tree growth, agroforestry, and commercial forestry management (Vine, 2003). The primary terrestrial options in the WESTCARB states of Arizona, California, Oregon, and Washington are:

- Reforestation of under-producing lands (including streamside forest restoration),

- Improved forest management,

- Forest protection and conservation, and

- Fuel treatments for the reduction of the risk of uncharacteristically severe fires (potentially with associated biomass energy generation).

Both Federal and State agencies will require a permit for any land-use changes or disturbances including improved forest management, forestation, and riparian conservation. The top three options mentioned above all involve some form of land-use changes or disturbances, and hence will have the same set of permitting requirements. Terrestrial sequestration options will be discussed in two separate categories: (1) land-use changes or disturbances and (2) biomass energy generation.

\subsubsection{Land-Use Changes or Disturbances}

There are three types of land ownership pertinent to terrestrial $\mathrm{CO}_{2}$ sequestration: Federal, State, and private. Tables below define the terrestrial $\mathrm{CO}_{2}$ sequestration permit/contracts requirements for the WESTCARB states of Arizona (Table 6), California (Table 7), Oregon (Table 8) and Washington (Table 9). Federal land can be managed by either the U.S. Department of Agriculture, U.S. Department of Interior (UDSI) through the National Park Services, Bureau of Land Management (BLM), or Bureau of Indian Affairs. Regulations affecting private land management depend on whether the land is classified as private forest land or private ranchland. 
Table 6. Potential Arizona permits/contracts for land-use changes or disturbances. (See Appendix I for an explanation of acronyms.)

\begin{tabular}{|c|c|c|c|}
\hline \multicolumn{2}{|c|}{ TYPE OF LAND } & $\begin{array}{l}\text { REGULATING } \\
\text { AGENCY }\end{array}$ & REGULATIONS CITED \\
\hline \multicolumn{2}{|c|}{ State land } & $\begin{array}{l}\text { State Land Dept. } \\
\text { Dept. of Fish \& Wildlife } \\
\text { DEQ (Water Quality) } \\
\text { U.S. Fish and Game }\end{array}$ & $\begin{array}{l}\text { ARS Title } 37-102 \text { and } 37-622 \\
\text { ARS Title } 17 \mathrm{Ch} 3 \\
\text { AAC Title } 18 \mathrm{Ch} 9 \\
\text { 50CFR } 17\end{array}$ \\
\hline \multirow[t]{4}{*}{$\begin{array}{l}\text { Federal } \\
\text { land }\end{array}$} & USDA & $\begin{array}{l}\text { USDA } \\
\text { Dept. of Fish and Game } \\
\text { U.S. Fish and Game }\end{array}$ & $\begin{array}{l}\text { 36CFR Ch1 part } 1 \\
\text { ARS Title } 17 \mathrm{Ch} 3 \\
\text { 50CFR17 }\end{array}$ \\
\hline & $\begin{array}{l}\text { USDI - } \\
\text { National } \\
\text { Parks }\end{array}$ & Not allowed & \\
\hline & $\begin{array}{l}\text { USDI - } \\
\text { BLM }\end{array}$ & $\begin{array}{l}\text { BLM } \\
\text { Dept. of Fish and Game } \\
\text { U.S. Fish and Game }\end{array}$ & $\begin{array}{l}\text { 43CFR part 5000-5510 } \\
\text { ARS Title } 17 \mathrm{Ch} 3 \\
\text { 50CFR17 }\end{array}$ \\
\hline & $\begin{array}{l}\text { USDI - } \\
\text { Tribal } \\
\text { land }\end{array}$ & $\begin{array}{l}\text { USDI } \\
\text { BLM } \\
\text { Local tribunal }\end{array}$ & $\begin{array}{l}\text { 25CFR part1 and } 163 \\
\text { All BLM regulations } \\
\text { HR3826 (Tribal Forest } \\
\text { Protection Act); local tribunal } \\
\text { laws }\end{array}$ \\
\hline \multirow[t]{2}{*}{$\begin{array}{l}\text { Private } \\
\text { land }\end{array}$} & $\begin{array}{l}\text { Forest } \\
\text { land }\end{array}$ & Same as State land & State land regulations \\
\hline & $\begin{array}{l}\text { Ranch } \\
\text { land }\end{array}$ & $\begin{array}{l}\text { County/city planning } \\
\text { DEQ (Water Quality) } \\
\text { Dept. of Fish and Game } \\
\text { U.S. Fish and Game }\end{array}$ & $\begin{array}{l}\text { Various county/city zoning codes } \\
\text { AAC Title } 18 \mathrm{Ch} 9 \\
\text { ARS Title } 17 \mathrm{Ch} 3 \\
50 \mathrm{CFR} 17\end{array}$ \\
\hline
\end{tabular}


Table 7. Potential California permits/contracts for land-use changes or disturbances. (See Appendix I for an explanation of acronyms.)

\begin{tabular}{|c|c|c|c|}
\hline \multicolumn{2}{|c|}{ TYPE OF LAND } & $\begin{array}{l}\text { REGULATING } \\
\text { AGENCY }\end{array}$ & REGULATIONS CITED \\
\hline \multicolumn{2}{|l|}{ State land } & $\begin{array}{l}\text { Dept. of Forestry \& Fire } \\
\text { Protection } \\
\text { Dept. of Fish and Game } \\
\text { CEQA } \\
\text { RWQCB } \\
\text { U.S. Fish and Game }\end{array}$ & $\begin{array}{l}\text { Pub Resource Code Div4 and 13; } \\
\text { California Forest Practice Act } \\
\text { 14CCR Div } 1 \\
\text { Pub Resource Code Div } 13 \\
\text { Water Code } 13000 \text { (Porter } \\
\text { Cologne Water Quality Act) } \\
\text { 50CFR17 }\end{array}$ \\
\hline \multirow[t]{4}{*}{$\begin{array}{l}\text { Federal } \\
\text { land }\end{array}$} & USDA & $\begin{array}{l}\text { USDA } \\
\text { Dept. of Fish and Game } \\
\text { U.S. Fish and Game } \\
\text { CEQA }\end{array}$ & $\begin{array}{l}\text { 36CFR Ch1 part } 1 \\
\text { 14CCR Div } 1 \\
\text { 50CFR17 } \\
\text { Pub Resource Code Div } 13\end{array}$ \\
\hline & $\begin{array}{l}\text { USDI - } \\
\text { National } \\
\text { Parks }\end{array}$ & Not allowed & \\
\hline & $\begin{array}{l}\text { USDI - } \\
\text { BLM }\end{array}$ & $\begin{array}{l}\text { BLM } \\
\text { Dept. of Fish and Game } \\
\text { U.S. Fish and Game }\end{array}$ & $\begin{array}{l}\text { 43CFR part 5000-5510 } \\
\text { 14CCR Div } 1 \\
\text { 50CFR17 }\end{array}$ \\
\hline & $\begin{array}{l}\text { USDI - } \\
\text { Tribal } \\
\text { land }\end{array}$ & $\begin{array}{l}\text { USDI } \\
\text { BLM } \\
\text { Local tribunal }\end{array}$ & $\begin{array}{l}\text { 25CFR part1 and } 163 \\
\text { All BLM regulations } \\
\text { HR3826 (Tribal Forest } \\
\text { Protection Act); local tribunal } \\
\text { laws }\end{array}$ \\
\hline \multirow[t]{2}{*}{$\begin{array}{l}\text { Private } \\
\text { land }\end{array}$} & $\begin{array}{l}\text { Forest } \\
\text { land }\end{array}$ & Same as State land & State land regulations \\
\hline & $\begin{array}{l}\text { Ranch } \\
\text { land }\end{array}$ & Same as State land & State land regulations \\
\hline
\end{tabular}


Table 8. Potential Oregon permits/contracts for land-use changes or disturbances. (See Appendix I for an explanation of acronyms.)

\begin{tabular}{|c|c|c|c|}
\hline \multicolumn{2}{|c|}{ TYPE OF LAND } & $\begin{array}{l}\text { REGULATING } \\
\text { AGENCY }\end{array}$ & REGULATIONS CITED \\
\hline \multicolumn{2}{|l|}{ State land } & $\begin{array}{l}\text { ODF } \\
\text { Dept. of Fish and Game } \\
\text { Div. of State Lands (if } \\
\text { impact waterways) } \\
\text { U.S. Army Corps of } \\
\text { Engineers } \\
\text { (if fill wetlands or } \\
\text { waterways) } \\
\text { U.S. Fish and Game }\end{array}$ & $\begin{array}{l}\text { OAR Ch629; ORS 527.610, } \\
\text { State Forest Management Plan } \\
\text { OAR Ch635 } \\
\text { ORS 195.795-196.990 } \\
\text { CWA Sec404 } \\
\text { 50CFR17 }\end{array}$ \\
\hline \multirow[t]{4}{*}{$\begin{array}{l}\text { Federal } \\
\text { land }\end{array}$} & USDA & $\begin{array}{l}\text { USDA } \\
\text { Dept. of Fish and Game } \\
\text { U.S. Fish and Game }\end{array}$ & $\begin{array}{l}\text { 36CFR Ch1 part } 1 \\
\text { OAR Ch635 } \\
\text { 50CFR17 }\end{array}$ \\
\hline & $\begin{array}{l}\text { USDI - } \\
\text { National } \\
\text { Parks }\end{array}$ & Not allowed & \\
\hline & $\begin{array}{l}\text { USDI - } \\
\text { BLM }\end{array}$ & $\begin{array}{l}\text { BLM } \\
\text { Dept. of Fish \& Game } \\
\text { U.S. Fish \& Game }\end{array}$ & $\begin{array}{l}\text { 43CFR part 5000-5510 } \\
\text { OAR Ch635 } \\
\text { 50CFR17 }\end{array}$ \\
\hline & $\begin{array}{l}\text { USDI - } \\
\text { Tribal } \\
\text { land }\end{array}$ & $\begin{array}{l}\text { USDI } \\
\text { BLM } \\
\text { Local tribunal }\end{array}$ & $\begin{array}{l}\text { 25CFR part1 and } 163 \\
\text { All BLM regulations } \\
\text { HR3826 (Tribal Forest } \\
\text { Protection Act); local tribunal } \\
\text { laws }\end{array}$ \\
\hline \multirow[t]{2}{*}{$\begin{array}{l}\text { Private } \\
\text { land }\end{array}$} & $\begin{array}{l}\text { Forest } \\
\text { land }\end{array}$ & Same as State land & $\begin{array}{l}\text { State land regulations except less } \\
\text { stringent }\end{array}$ \\
\hline & $\begin{array}{l}\text { Ranch } \\
\text { land }\end{array}$ & $\begin{array}{l}\text { ODA (agriculture water } \\
\text { quality review) } \\
\text { Div. of State Lands (if } \\
\text { impact waterways) } \\
\text { U.S. Army Corps of } \\
\text { Engineers (if fill wetlands } \\
\text { or waterways) } \\
\text { County planning dept. }\end{array}$ & $\begin{array}{l}\text { ORS603 Div 80, } 90 \text { and 95; } \\
\text { SB1010 } \\
\text { ORS 195.795-196.990 } \\
\text { CWA Sec404 } \\
\text { Various county planning } \\
\text { regulations }\end{array}$ \\
\hline
\end{tabular}


Table 9. Potential Washington permits/contracts for land-use changes or disturbances. (See Appendix I for an explanation of acronyms.)

\begin{tabular}{|c|c|c|c|}
\hline \multicolumn{2}{|c|}{ TYPE OF LAND } & $\begin{array}{l}\text { REGULATING } \\
\text { AGENCY }\end{array}$ & REGULATIONS CITED \\
\hline \multicolumn{2}{|c|}{ State land } & $\begin{array}{l}\text { DNR } \\
\text { Dept. of Fish and Game } \\
\text { Dept. of Ecology (SEPA } \\
\quad \text { requirements) } \\
\text { (Water Right Permit) } \\
\text { U.S. Fish and Game }\end{array}$ & $\begin{array}{l}\text { WAC Title } 222 \\
\text { WAC Title } 220 \text { and } 232 \\
\text { RCW43.21C } \\
\text { WAC Title } 173-152 \text { and } 173-173 \\
\text { 50CFR17 }\end{array}$ \\
\hline \multirow[t]{4}{*}{$\begin{array}{l}\text { Federal } \\
\text { land }\end{array}$} & USDA & $\begin{array}{l}\text { USDA } \\
\text { Dept. of Fish and Game } \\
\text { U.S. Fish and Game }\end{array}$ & $\begin{array}{l}\text { 36CFR Ch1 part } 1 \\
\text { WAC Title } 220 \text { and } 232 \\
\text { 50CFR } 17\end{array}$ \\
\hline & $\begin{array}{l}\text { USDI - } \\
\text { National } \\
\text { Parks }\end{array}$ & Not allowed & \\
\hline & $\begin{array}{l}\text { USDI - } \\
\text { BLM }\end{array}$ & $\begin{array}{l}\text { BLM } \\
\text { Dept. of Fish and Game } \\
\text { U.S. Fish and Game }\end{array}$ & $\begin{array}{l}\text { 43CFR part 5000-5510 } \\
\text { WAC Title } 220 \text { and } 232 \\
\text { 50CFR } 17\end{array}$ \\
\hline & $\begin{array}{l}\text { USDI - } \\
\text { Tribal } \\
\text { land }\end{array}$ & $\begin{array}{l}\text { USDI } \\
\text { BLM } \\
\text { Local tribunal }\end{array}$ & $\begin{array}{l}\text { 25CFR part1 and } 163 \\
\text { All BLM regulations } \\
\text { HR3826 (Tribal Forest } \\
\text { Protection Act); local tribunal } \\
\text { laws }\end{array}$ \\
\hline \multirow[t]{2}{*}{$\begin{array}{l}\text { Private } \\
\text { land }\end{array}$} & $\begin{array}{l}\text { Forest } \\
\text { land }\end{array}$ & Same as State land & State land regulations \\
\hline & $\begin{array}{l}\text { Ranch } \\
\text { land }\end{array}$ & $\begin{array}{l}\text { County planning dept. } \\
\text { Dept. of Ecology (water } \\
\text { right permit) }\end{array}$ & $\begin{array}{l}\text { Various county planning } \\
\text { regulations } \\
\text { WAC Title } 173-152 \text { and } 173-173\end{array}$ \\
\hline
\end{tabular}

\subsubsection{Biomass Energy Generation}

Arizona, California, Oregon, and Washington all have the same permitting requirements for the biomass $\mathrm{CO}_{2}$ sequestration option. Besides the State or Federal requirements discussed in the previous section, local air district, water board, and county/city planning department rules will be applicable.

Biomass is not yet economical, but can be if government will provide subsidies or tax credits. Beside local county/city planning department regulations, building of power plant for biomass energy generation will require local air district approval as well as an NPDES permit from the water board for the effluent discharge. Dead wood removal also requires a contract/permit from the land owner. 
Table 10. Biomass permit contract requirements

\begin{tabular}{|l|l|}
\hline REGULATING AGENCY & REGULATIONS CITED \\
\hline State or Federal & See existing State land or Federal land regulations \\
\hline Local air district & New source review (BACT); air permit \\
\hline Water board & NPDES permit; water right permit \\
\hline City/county planning dept. & $\begin{array}{l}\text { Conditional use permit; City/county planning } \\
\text { building permit }\end{array}$ \\
\hline
\end{tabular}

\section{Conclusions and Recommendations}

In order for $\mathrm{CO}_{2}$ sequestration to be viable, EPA will first have to standardize injection regulations and government will possibly need to give some tax incentive or credit.

Carbon dioxide generated from industrial activities can be captured, transported and sequestered either by injecting into appropriate geologic formations, or capturing through carbon intake into the terrestrial ecosystems. EPA will probably make no distinction between storage and disposal into any medium, nor if in gaseous or liquid phase. For injection into appropriate geologic formations, options include storage in:

- Oil and gas reservoirs,

- Saline formations,

- Unmineable coal beds, and

- Salt caverns.

The permit requirements for each of the above options have been documented and their respective regulations cited. It is not yet clear how the classification of $\mathrm{CO}_{2}$ as product or waste will influence the type of injection well or the regulating agency. EPA will most probably not differentiate between storage and disposal. Regardless of the well classification, the well will have the same standard; EPA is endeavoring to ensure a universal standard and perhaps classification to which all agencies will adhere. Ultimately, EPA, with the States' input will have to decide on the proper classification of $\mathrm{CO}_{2}$. The classification is of lesser importance than the regulatory operational concerns such as the requirements based on criteria, standards, geology, etc., for each $\mathrm{CO}_{2}$ injection well.

Terrestrial $\mathrm{CO}_{2}$ sequestration involves carbon conservation, substitution and storage. The primary terrestrial options for the West Coast Regional Partnership states of Arizona, California, Oregon, and Washington are:

- Reforestation of under-producing lands (including streamside forest restoration),

- Improved forest management,

- Forest protection and conservation, and

- Fuel treatments for the reduction of risk of uncharacteristically severe fires (potentially with associated biomass energy generation). 
The required permit/contract for any land use changes/disturbances and biomass energy generation have been summarized for each state. To date, biomass energy generation is not feasible without some form of government subsidy or tax credit.

Table 11 (below) shows the relative efforts in obtaining the required permits for $\mathrm{CO}_{2}$ sequestration for the different injection and terrestrial options pertinent to the WESTCARB region. Injection of $\mathrm{CO}_{2}$ for EOR-related projects is allowed by all states and therefore the permit is relatively easy to obtain. States with primacy will control the Class II well injection through their respective state agencies and EPA for those states without the primacy status. For the relative efforts involved in obtaining terrestrial $\mathrm{CO}_{2}$ permits, most terrestrial options fall between two extreme cases: (1) already-in-operation (e.g., EOR), to (2) not permitted (e.g., harvesting in National Parks).

Table 11. Table of relative efforts

\begin{tabular}{|l|l|}
\hline $\begin{array}{l}\text { OPTIONS } \\
\text { (from easy to difficult) }\end{array}$ & REASONS \\
\hline EOR & $\begin{array}{l}\text { In operation } \\
\text { Class II wells for State with primacy, EPA without } \\
\text { primacy }\end{array}$ \\
\hline $\begin{array}{l}\text { U.S. Dept. of Agriculture - } \\
\text { Forest Service }\end{array}$ & $\begin{array}{l}\text { Permit from U.S. Department of Agriculture, Forest } \\
\text { Service } \\
\text { U.S. Fish and Game (endangered species review) } \\
\text { State Fish and Game (State endangered species } \\
\text { review) }\end{array}$ \\
\hline $\begin{array}{l}\text { U.S. Dept. of Interior - } \\
\text { BLM }\end{array}$ & $\begin{array}{l}\text { Permit from BLM } \\
\text { U.S. Fish and Game (endangered species review) } \\
\text { State Fish and Game (State endangered species } \\
\text { review) }\end{array}$ \\
\hline State forestlands & $\begin{array}{l}\text { Permit from State Forest and Fire Dept. } \\
\text { State Dept. of Fish and Game } \\
\text { U.S. Fish and Game } \\
\text { Water right or usage permit } \\
\text { U.S. Army Corps of Engineers (Oregon only if fills } \\
\text { wetlands or waterways) } \\
\text { Div. of State Lands (Oregon only if impacts } \\
\text { waterways) } \\
\text { CEQA (CA) SEPA (WA) review }\end{array}$ \\
\hline Private forestlands & $\begin{array}{l}\text { Permit from State Forest and Fire Dept. } \\
\text { State Dept. of Fish and Game } \\
\text { U.S. Fish and Game } \\
\text { Water right or usage permit } \\
\text { County planning dept. (Oregon and Washington only) } \\
\text { U.S. Army Corps of Engineers (Oregon only if fills } \\
\text { wetlands or waterways) }\end{array}$ \\
\hline
\end{tabular}




\begin{tabular}{|l|l|}
\hline & $\begin{array}{l}\text { Div. of State Lands (Oregon only if impacts } \\
\text { waterways) } \\
\text { CEQA (CA) SEPA (WA) review }\end{array}$ \\
\hline $\begin{array}{l}\text { U.S. Dept. of the Interior - } \\
\text { Indian Lands }\end{array}$ & $\begin{array}{l}\text { Permit from BLM } \\
\text { U.S. Fish and Game (Endangered species review) } \\
\text { State Fish and Game (State endangered species } \\
\text { review) } \\
\text { Local tribunal laws }\end{array}$ \\
\hline $\begin{array}{l}\text { Subsurface Storage and } \\
\text { Disposal }\end{array}$ & $\begin{array}{l}\text { Uncertain depending on classification of } \mathrm{CO}_{2} \text { as } \\
\text { product or waste }\end{array}$ \\
\hline Biomass & $\begin{array}{l}\text { Local air permit (BACT, new source review) } \\
\text { NPDES permit } \\
\text { County planning dept. } \\
\text { Permit from State forest and fire dept. } \\
\text { State Dept. of Fish and Game } \\
\text { U.S. Fish and Game } \\
\text { Water right or usage permit } \\
\text { U.S. Army Corps of Engineers (Oregon only if fills } \\
\text { wetlands or waterways) } \\
\text { Div. of State Lands (Oregon only if impacts } \\
\text { waterways) } \\
\text { CEQA (CA) SEPA (WA) review } \\
\text { Uneconomical without tax credit or government } \\
\text { subsidy }\end{array}$ \\
\hline No harvesting allowed \\
\hline U.S. Dept. of Interiors - \\
National Parks
\end{tabular}

\section{References}

Cathcart, Jim, March 2004, written communication, Oregon Department of Forestry.

Hart's E\&Pnet, http://www.eandpnet.com/.

Herzog, H., E. Drake, and E. Adams; 1997; $\mathrm{CO}_{2}$ Capture, Reuse, and Storage Technologies for Mitigating Global Climate Change; DOE Order No. DE-AF2296PC01257.

Interstate Oil and Gas Compact Commission (IOGCC), 2005, A Regulatory Framework for Carbon Capture and Geological Storage, DOE Order No. DE-FC26-03NT41994.

Veil, John, 2002, Regulatory Issues Affecting Management of Produced Water From Coal Bed Methane Wells, prepared for DOE, Office of Fossil Energy, W-31-109-ENG38.

Vine, Edward, 2003, Regulatory Constraints to Carbon Sequestration in Terrestrial Ecosystems and Geologic Formations-A California Perspective: Mitigation and Adaptation Strategies for Global Change, 9(1), 77-95. 


$\begin{array}{ll}\text { Appendix } & \\ \text { AB } & \text { Assembly Bill } \\ \text { ACC } & \text { Alaska Administrative Code } \\ \text { ACC } & \text { Arizona Administrative Code } \\ \text { ARS } & \text { Arizona Revised Statues } \\ \text { AST } & \text { Aboveground storage tank } \\ \text { BACT } & \text { Best Available Control Technology } \\ \text { BLM } & \text { Bureau of Land Management } \\ \text { ECBM } & \text { Enhanced Coal-Bed Methane } \\ \text { CCR } & \text { California Code of Regulations } \\ \text { CEQA } & \text { California Environmental Quality Act } \\ \text { CFR } & \text { Code of Federal Regulations } \\ \text { DEP } & \text { Department of Environmental Protection } \\ \text { DEQ } & \text { Department of Environmental Quality } \\ \text { DNR } & \text { Department of Natural Resources } \\ \text { DOGGR } & \text { California Division of Oil, Gas and Geothermal Resources } \\ \text { DOM } & \text { Division of Minerals } \\ \text { DOT } & \text { Department of Transportation } \\ \text { EGR } & \text { Enhanced gas recovery } \\ \text { EOR } & \text { Enhanced oil recovery } \\ \text { EPA } & \text { Environmental Protection Agency } \\ \text { HR } & \text { House Rule } \\ \text { FERC } & \text { Federal Energy Regulatory Commission } \\ \text { NAC } & \text { Nevada Administrative Code } \\ \text { NPDES } & \text { National Pollutant Discharge and Elimination System } \\ \text { NRS } & \text { Nevada Revised Statutes } \\ \text { OAR } & \text { Oregon Administrative Rule } \\ \text { ODA } & \text { Oregon Department of Agriculture } \\ \text { ODF } & \text { Oregon Department of Forestry } \\ \text { OGCC } & \text { Oil and Gas Conservation Commission } \\ \text { OSHA } & \text { Occupational Safety and Health Administration } \\ \text { PUC } & \text { Public Utility Commission } \\ \text { RWQCB } & \text { Regional Water Quality Control Board } \\ \text { SEPA } & \text { State Environmental Protection Act } \\ \text { USDA } & \text { U.S. Department of Agriculture } \\ \text { USDI } & \text { U.S. Department of Interior } \\ \text { UIC } & \text { Underground Injection Control } \\ \text { UTC } & \text { Utilities and Transportation Commission } \\ \text { WAC } & \text { Washington Administrative Code } \\ & \\ & \end{array}$

